\title{
Casein polymorphism heterogeneity influences casein micelle size in milk of individual cows
}

\author{
L. Day, ${ }^{*} \dagger^{1}$ R. P. W. Williams, ${ }^{*}$ D. Otter, $\dagger$ and M. A. Augustin ${ }^{*}$ \\ ${ }^{*}$ CSIRO Food and Nutrition Flagship, 671 Sneydes Road, Werribee, VIC 3030, Australia \\ †AgResearch Ltd. Grasslands Research Centre, Tennent Drive, Palmerston North 4442, New Zealand
}

\begin{abstract}
Milk samples from individual cows producing small $(148-155 \mathrm{~nm})$ or large $(177-222 \mathrm{~nm})$ casein micelles were selected to investigate the relationship between the individual casein proteins, specifically $\kappa$ - and $\beta$-casein phenotypes, and casein micelle size. Only $\kappa$-casein AA and $\beta$-casein $\mathrm{A}^{1} \mathrm{~A}^{1}, \mathrm{~A}^{1} \mathrm{~A}^{2}$ and $\mathrm{A}^{2} \mathrm{~A}^{2}$ phenotypes were found in the large casein micelle group. Among the small micelle group, both $\kappa$-casein and $\beta$-casein phenotypes were more diverse. $\kappa$-Casein $\mathrm{AB}$ was the dominant phenotype, and 3 combinations $(\mathrm{AA}, \mathrm{AB}$, and $\mathrm{BB}$ ) were present in the small casein micelle group. A considerable mix of $\beta$-casein phenotypes was found, including $\mathrm{B}$ and I variants, which were only found in the small casein micelle group. The relative amount of $\kappa$-casein to total casein was significantly higher in the small micelle group, and the nonglycosylated and glycosylated $\kappa$-casein contents were higher in the milks with small casein micelles (primarily with $\kappa$-casein $\mathrm{AB}$ and $\mathrm{BB}$ variants) compared with the large micelle group. The ratio of glycosylated to nonglycosylated $\kappa$-casein was higher in the milks with small casein micelles compared with the milks with large casein micelles. This suggests that although the amount of $\kappa$-casein (both glycosylated and nonglycosylated) is associated with micelle size, an increased proportion of glycosylated $\kappa$-casein could be a more important and favorable factor for small micelle size. This suggests that the increased spatial requirement due to addition of the glycosyl group with increasing extent of glycosylation of $\kappa$-casein is one mechanism that controls casein micelle assembly and growth. In addition, increased electrostatic repulsion due to the sialyl residues on the glycosyl group could be a contributory factor.
\end{abstract}

Key words: casein micelle size, $\kappa$-casein phenotype, $\beta$-casein phenotype, glycosylation

\footnotetext{
Received December 25, 2014.

Accepted February 13, 2015.

${ }^{1}$ Corresponding author: li.day@agresearch.co.nz
}

\section{INTRODUCTION}

Casein micelles play an essential role in the processing of milk and its conversion to various dairy products. Caseins exist as colloidal micelles, the major functions of which are to transport proteins, calcium, and phosphate in high concentrations that would otherwise be insoluble in water and to provide adequate nutrients to young calves (Holt and Carver, 2012). There is still no clear consensus about the fine structure of the micelle assembly and how it is influenced by the various genetic variants of the casein protein species (Holt, 1992; Farrell et al., 2006; Horne, 2006). The sizes of casein micelles in milks from individual cows can vary considerably from $\sim 150$ to $230 \mathrm{~nm}$ (de Kruif and Huppertz, 2012; Bijl et al., 2014). The variation in casein micelle size does not appear to correlate with age, milk production, or lactation stage of the cows or with the fat or protein content of the milk (de Kruif and Huppertz, 2012). The secretion of casein proteins and micelle assembly take place within the cow's mammary gland. Amino acids and their metabolic precursors are actively transported into the secretory epithelial cells, where proteins are assembled and inserted into the lumen of the endoplasmic reticulum (Farrell et al., 2006). The proteins are then transported through the Golgi apparatus. The caseins are phosphorylated by a calcium-activated membranebound kinase to begin the process of calcium transport (Bingham and Farrell, 1974). The gradual incorporation of calcium, phosphate, and casein leads to the formation of casein micelles and ensures the effective transport of these vital minerals in high concentrations, which otherwise would not be possible. Through the binding of calcium and the accretion of phosphate, the colloidal casein micelles are formed and secreted into the lumen of the mammary gland to be ultimately expressed as milk. The main pathway of posttranslational modification of $\kappa-\mathrm{CN}$ involves the following steps: attachment of one phosphate residue, incorporation into the micelle structure, and glycosylation (Takeuchi et al., 1984; Dziuba and Minkiewicz, 1996). It is accepted that $\kappa-\mathrm{CN}$ is distributed throughout the micelle with a 
higher concentration at the surface (Holt, 1992; Horne, 2009; Dalgleish, 2011).

The relationship between casein protein variants, in particular $\kappa$-CN levels, genotypes, and phenotypes, and the degree of glycosylation and casein micelle size have been studied using fractionation from bulk milk and in milks from individual cows. So far, the results from the bulk milk studies, where micelles have been separated by centrifugation, have been inconsistent with regard to the level of glycosylation of $\mathrm{k}-\mathrm{CN}$ in relation to casein micelles of different sizes in different studies (Dalgleish, 1986; O'Connell and Fox, 2000). Early work by McGann et al. (1980) demonstrated an inverse linear relationship between the $\kappa-\mathrm{CN}$ content and micelle surface-to-volume ratio for fractionated micelles and surface area for artificial micelles. However, other work did not provide conclusive evidence of the relationship between $\kappa-\mathrm{CN}$ content and the hydrodynamic radius of the micelles (de Kruif and Huppertz, 2012). When individual milks were examined, samples with a smaller average micelle size were associated with the $\kappa-\mathrm{CN} B$ variant and a higher proportion of glycosylated $\kappa$-CN compared with milk samples with a larger micelle size (Lodes et al., 1996; Bijl et al., 2014). A recent study of Montbéliarde cows in the Netherlands reported by Bijl et al. (2014) suggested that the A and B genetic variants of $\kappa-\mathrm{CN}$ and differences in the amount of glycosylated $\kappa-\mathrm{CN}$ as a fraction of total $\kappa-\mathrm{CN}$ appear to correlate well with average casein micelle size. The B variant of $\kappa-\mathrm{CN}$ and a higher relative amount of glycosylated $\kappa-\mathrm{CN}$ (to total $\mathrm{CN}$ ) were associated with milks with smaller average casein micelle size (average 170 $\mathrm{nm}$ ), whereas the A variant of $\kappa-\mathrm{CN}$ was dominant in milks with a larger average casein micelle size (average $207 \mathrm{~nm})$.

The correlations between micelle size and casein protein composition are still up for debate because of the different results reported in the literature. It is not surprising that most of the research for the understanding of genetic links with the functionality of casein micelles has been focused on the relationship between $\kappa-\mathrm{CN}$ variants, micelle size, and the functional properties of milk. There is no consensus about the relationship between micelle size and the extent of $\kappa$-CN glycosylation. Differences in the preparation of the casein micelle fractions, analysis, and the definitions of the sizes of "large" and "small" micelles by various authors could explain some of the inconsistency in the results reported in the literature. On the other hand, even though evidence is emerging with regard to poor coagulation properties associated with $\beta-\mathrm{CN} \mathrm{A}^{2} \mathrm{~A}^{2}$ genotype (Frederiksen et al., 2011; Jensen et al., 2012a,b; Vallas et al., 2012; Poulsen et al., 2013), the genetic variants of the $\beta-\mathrm{CN}$ in relation to micelle size have been examined to a much lesser extent. Therefore, the aim of this work was to investigate polymorphisms of $\kappa-\mathrm{CN}$ and $\beta-\mathrm{CN}$ and the degree of $\kappa$ - $\mathrm{CN}$ glycosylation in relation to casein micelle size in milk from individual Australian Holstein-Friesian cows. The casein variants and their posttranslational modification could be the major determining factors controlling the casein micelle assembly and its size. Such knowledge could provide new insights for genetic selection of cows and milk quality to improve processing efficiency and dairy product quality.

\section{MATERIALS AND METHODS}

\section{Milk Samples}

Milk samples were obtained from 30 Holstein-Friesian cows of mixed age from the research herd maintained at the Department of Environment and Primary Industries (DEPI) at Ellinbank, Victoria, Australia $\left(38^{\circ} 14^{\prime} \mathrm{S}\right.$, $145^{\circ} 56^{\prime} \mathrm{E}$ ). Two samples were collected from each cow, $21 \mathrm{~d}$ apart, during the 35-d period between November 8 and December 13, 2011. At each sampling point, milk yield was measured at consecutive afternoon and morning milkings using a DeLaval Alpro milk metering system (DeLaval International AB, Tumba, Sweden). At the same time, in-line milk meters (DeLaval International $\mathrm{AB}$ ) were used to collect a representative sample (approximately 1\%) of the total milk of each cow sampled. Samples from the afternoon and morning milkings were pooled to give a sample representing the 24-h output of the cow. All cows had calved in late winter/early spring. The average DIM was 97, ranging between 39 and 141. They were milked twice daily through a common dairy parlor (at approximately 0600 and $1500 \mathrm{~h}$ ). In general, cows were managed as a single herd following typical practices for this region and grazed perennial ryegrass pasture supplemented with cracked wheat grain offered in the dairy and pasture silage in the paddock.

Samples of each milk $(100 \mathrm{~mL})$ were skimmed by centrifugation (J6-HC, Beckman, Mount Waverley, Melbourne, Australia) at $3,000 \times g$ for $15 \mathrm{~min}$ at $15^{\circ} \mathrm{C}$, followed by standing at $4^{\circ} \mathrm{C}$ for $>30 \mathrm{~min}$ for the cream layer to harden. The cream layer was then removed. The remaining cream from the surface of the sample was aspirated using a transfer pipette or vacuum system.

\section{Total Protein Content}

Protein concentrations in skim milk were determined using a Leco FP-2000 nitrogen analyzer (Leco Australia 
Pty Ltd., Castle Hill, NSW, Australia) according to the manufacturer's instructions using EDTA as standard.

\section{Dynamic Light Scattering Measurement}

The sizes of casein micelles were determined using 2 methods: dynamic light scattering and size exclusion chromatography (SEC). Dynamic light scattering was performed using a Malvern Zetasizer Nano ZS (Malvern, Worcestershire, UK). Skim milk samples were diluted 100-fold in deionized water. Measurements were made using a scattering angle of $173^{\circ}$ and laser with a wavelength of $633 \mathrm{~nm}$. A cumulate analysis correlation function was used to obtain the intensity mean diameter (z-average diameter) of each sample using a viscosity of $1 \mathrm{mPa} \cdot \mathrm{s}$ and a refractive index of $\mathrm{n}=1.343$. At least 2 cumulant $\mathrm{z}$-average measurements were obtained for each sample and duplicate samples were measured for each milk.

\section{Size Exclusion Chromatography}

Size exclusion chromatography of unfiltered milk samples was performed on Sephacryl S-1000SF (Amersham Bioscience Pty Ltd., Baulkham Hills, NSW, Australia). Milk samples were diluted 1:1 with elution buffer $\left(50 \mathrm{~m} M \mathrm{NaCl}, 20 \mathrm{~m} M\right.$ Tris, $3 \mathrm{mM} \mathrm{CaCl}_{2}, 0.2 \mathrm{~g} / \mathrm{L}$ $\mathrm{NaN}_{3}, \mathrm{pH}$ 6.7) and applied to the column of Sephacryl S-1000SF $(1.6 \mathrm{~cm}$ diameter $\times 98 \mathrm{~cm}$ long, Amersham Bioscience Pty Ltd.). The column was then eluted at $0.56 \mathrm{~mL} / \mathrm{min}$ using a Shimadzu Prominance HPLC system (Shimadzu, Tokyo, Japan), including a SCL10A system controller LC-10AD pump, SIL-10AD auto injector, and SPD-10A US-VIS detector set at $280 \mathrm{~nm}$. The total running time was $450 \mathrm{~min}$.

\section{Reversed Phase-HPLC}

Caseins were separated and characterized according to a method adapted from Bobe et al. (1998) and Bordin et al. (2001). Skim milk samples were analyzed for milk proteins using a BioRad Hi-Pore Reversed Phase column (RP-318, $250 \times 4.6 \mathrm{~mm}$, Bio-Rad Laboratories Pty Ltd., Auckland, New Zealand). Samples were prepared by mixing $200 \mu \mathrm{L}$ of the skim milk with 600 $\mu \mathrm{L}$ of $6 M$ guanidine hydrochloride, $0.1 M$ Bis-Tris, and $5.37 \mathrm{~m} M$ sodium citrate, $\mathrm{pH} 7$, and standing for $1 \mathrm{~h}$. The sample mixture $(500 \mu \mathrm{L})$ was then added to $490 \mu \mathrm{L}$ of $4.5 M$ guanidine hydrochloride and $10 \mu \mathrm{L}$ of 2 -mercaptoethanol, and filtered through a $0.45-\mu \mathrm{m}$ filter. Individual milk proteins were separated on the C18 column using a gradient from approximately 25 to $50 \%$ acetonitrile in water containing $0.1 \%$ trifluoroacetic acid. Compounds in the column eluent were detected by absorbance at $280 \mathrm{~nm}$. The following bovine milk proteins were purchased from Sigma (St. Louis, MO): $\kappa-\mathrm{CN}(\mathrm{C}-0406), \alpha-\mathrm{CN}(\mathrm{C}-6780), \beta-\mathrm{CN}$ (C-6905), $\alpha-\mathrm{LA}$ (L-5385), $\beta$-LG B (L-8005), and $\beta$-LG A (L-7880), and used for calibration. All analyses were carried in duplicate for each milk sample collected at 2 separate time points.

\section{Liquid Chromatography-Mass Spectrometry}

For genetic variant identification of individual milk proteins, samples were injected onto a $1 \mathrm{~mL}$ Resource RPC column (Pharmacia Biotech, Uppsala, Sweden), which was equilibrated in $95 \%$ solvent A $(0.1 \%$, vol/ vol, formic acid in Milli-Q water) and desalted using a 2-min isocratic period before mass spectrometric analysis. The proteins were then eluted by a 2 -min linear gradient to $95 \%$ solvent B $(0.1 \%$, vol/vol, formic acid, 100\%, vol/vol, acetonitrile) into a Thermo LTQ linear ion-trap mass spectrometer (Thermo Electron Corporation, San Jose, CA) using positive electrospray ionization with the ion trap programmed to collect an MS1 spectrum from 700 to $2,000 \mathrm{~m} / \mathrm{z}$. The capillary temperature was $275^{\circ} \mathrm{C}$ and source ionization voltage was $-4,000 \mathrm{~V}$. Spectra were deconvoluted using MagTran (the magic transformer) freeware deconvolution software for electrospray spectra (http://www.geocities.com/SiliconValley/Hills/2679/magtran.html).

For identification, fractions were also collected from the reversed phase (RP)-HPLC analysis and freezedried, resolubilized in $0.1 \%$ formic acid, and analyzed by liquid chromatography-mass spectrometry (LCMS).

\section{Statistical Analysis}

The statistical significance of the results is indicated by the calculation of least significant differences between means using ANOVA at 95\% confidence intervals using Microsoft Excel (Microsoft Corp., Redmond, WA).

\section{RESULTS}

\section{Casein Micelle Size from Individual Milk Samples}

A group of 30 cows producing milk with either predominantly larger or smaller casein micelles were selected based on a larger survey of 60 to 70 cows conducted in spring 2011 (Williams et al., 2014). The average sizes of the casein micelles from individual skim milk samples of these cows were in the range of 177 to $222 \mathrm{~nm}$ for the 15 cows in the large casein micelle group 
Table 1. Average casein micelle size, total protein content, and phenotype variants of $\kappa$-CN, $\beta$-CN, and $\beta$-LG identified by reversed phase-HPLC and liquid chromatography-mass spectrometry (LC-MS) in each individual milk samples

\begin{tabular}{|c|c|c|c|c|c|c|}
\hline Milk sample no. & $\begin{array}{l}\text { Cow } \\
\text { code }\end{array}$ & $\begin{array}{c}\text { Average } \\
\text { micelle size }(\mathrm{nm})\end{array}$ & $\begin{array}{c}\text { Total protein } \\
\text { (in skim milk; \%) }\end{array}$ & $\beta-\mathrm{CN}$ & $\kappa-\mathrm{CN}$ & $\beta$-LG \\
\hline \multicolumn{7}{|c|}{ Large micelle group } \\
\hline 3 & 820 & 190.8 & 2.92 & $\mathrm{~A}^{1} \mathrm{~A}^{2}$ & AA & $\mathrm{AB}$ \\
\hline 4 & 5622 & 222.4 & 3.45 & $\mathrm{~A}^{1} \mathrm{~A}^{2}$ & $\mathrm{AA}$ & $\mathrm{AB}$ \\
\hline 5 & 6862 & 181.2 & 3.07 & $\mathrm{~A}^{1} \mathrm{~A}^{2}$ & AA & $\mathrm{AB}$ \\
\hline 8 & 2047 & 191.9 & 3.26 & $\mathrm{~A}^{1} \mathrm{~A}^{1}$ & AA & $\mathrm{AB}$ \\
\hline 9 & 4576 & 182.1 & 3.49 & $\mathrm{~A}^{1} \mathrm{~A}^{1}$ & AA & $\mathrm{AB}$ \\
\hline 10 & 2207 & 178.6 & 3.06 & $\mathrm{~A}^{2} \mathrm{~A}^{2}$ & AA & $\mathrm{AB}$ \\
\hline 11 & 4548 & 187.3 & 3.93 & $\mathrm{~A}^{2} \mathrm{~A}^{2}$ & AA & AA \\
\hline 12 & 5618 & 183.6 & 2.66 & $\mathrm{~A}^{2} \mathrm{~A}^{2}$ & AA & AA \\
\hline 13 & 6868 & 184.6 & 3.68 & $\mathrm{~A}^{2} \mathrm{~A}^{2}$ & $\mathrm{AA}$ & $\mathrm{BB}$ \\
\hline 14 & 9501 & 181.7 & 3.42 & $\mathrm{~A}^{2} \mathrm{~A}^{2}$ & $\mathrm{AA}$ & $\mathrm{BB}$ \\
\hline 19 & 3056 & 150.4 & 2.85 & $\mathrm{~A}^{1} \mathrm{I}$ & $\mathrm{AB}$ & BB \\
\hline 20 & 3040 & 151.4 & 3.14 & $\mathrm{~A}^{2} \mathrm{I}$ & $\mathrm{AB}$ & $\mathrm{AB}$ \\
\hline 21 & 773 & 152.6 & 3.50 & $\mathrm{~A}^{1} \mathrm{~A}^{2}$ & $\mathrm{AB}$ & $\mathrm{AB}$ \\
\hline 22 & 711 & 152.8 & 3.33 & $\mathrm{~A}^{2} \mathrm{I}$ & $\mathrm{AB}$ & $\mathrm{BB}$ \\
\hline 23 & 4574 & 154.8 & 3.28 & $\mathrm{~A}^{1} \mathrm{I}$ & $\mathrm{AB}$ & $\mathrm{AB}$ \\
\hline 24 & 6810 & 149.0 & 3.22 & $\mathrm{~A}^{1} \mathrm{~A}^{2}$ & $\mathrm{AB}$ & $\mathrm{AB}$ \\
\hline 25 & 3058 & 152.6 & 3.55 & $\mathrm{~A}^{1} \mathrm{~A}^{2}$ & $\mathrm{AB}$ & $\mathrm{AB}$ \\
\hline 26 & 6819 & 148.1 & 3.54 & $\mathrm{~A}^{1} \mathrm{~A}^{1}$ & $\mathrm{AB}$ & $\mathrm{AB}$ \\
\hline 27 & 3066 & 151.0 & 3.32 & $\mathrm{~A}^{1} \mathrm{~A}^{1}$ & $\mathrm{AB}$ & $\mathrm{AA}$ \\
\hline 28 & 9510 & 155.7 & 3.44 & $\mathrm{~A}^{2} \mathrm{~B}$ & $\mathrm{AB}$ & $\mathrm{AB}$ \\
\hline 29 & 6801 & 150.7 & 3.20 & $\mathrm{~A}^{1} \mathrm{I}$ & BB & AA \\
\hline 30 & 4560 & 152.8 & 4.41 & I?B & $\mathrm{BB}$ & $\mathrm{AB}$ \\
\hline
\end{tabular}

(mean $186.9 \pm 12.4 \mathrm{~nm}$ ) and 148 to $155 \mathrm{~nm}$ for the 15 cows in the small micelle group (mean $151.4 \pm 2.2 \mathrm{~nm}$ ) respectively (Table 1 ).

The individual milk samples were also analyzed by SEC. Using this technique, further resolution of the distribution of the particles in milk was obtained, allowing separation of 6 differently sized populations within the sample. These are indicated in Figure 1 as follows: peak $1=$ large casein micelles with diameters $>200 \mathrm{~nm}$; peak $2=$ small casein micelles with diameters in the range 160 to $80 \mathrm{~nm}$; peak $3=$ small protein aggregates and very small micelles with diameters 80 to $37 \mathrm{~nm}$; peak $4=$ whey proteins; peak $5=$ small peptides; and peak $6=$ small aromatic molecules (Williams et al., 2008).

The typical profiles obtained from selected milk samples in the large (A) and small (B) micelle groups are shown in Figure 1A and 1B, respectively. All milks in either the large or small micelle group exhibited similar profiles for each group. We found distinctive differences in the SEC profiles of milks between the large and small micelle groups. Peak 1, representing micelles of the average size $>200 \mathrm{~nm}$, was present in all milks in the large group (Figure 1A). This peak was largely diminished in the milks grouped as small micelles (Figure 1B). The second broad peak accounted for the smaller size of micelle distribution (particles with diameters in the range $160-80 \mathrm{~nm}$ ). This second peak was larger than the first peak in the milks in the small micelle group compared with those in the large micelle group. This shows that the milks in the large micelle group had proportionally more of the largest micelles. The ratio of peak 1 to peak 2 could be used as an indication of the different proportions of the large and small casein micelles in the milks containing predominantly large or small casein micelles (Williams et al., 2014).

The total protein contents of each skim milk sample are shown in Table 1. Although some variation of the protein content was found for the 15 milk samples in large and small micelle groups, overall there was no statistically significant difference between the 2 groups (i.e., $3.27 \pm 0.34 \%$ for the large micelle group and 3.43 $\pm 0.36 \%$ for the small micelle group). We also detected no significant differences in the gross composition of the milk, the age of the cows, or in milk production (L/d) between the 2 groups (Williams et al., 2014). 


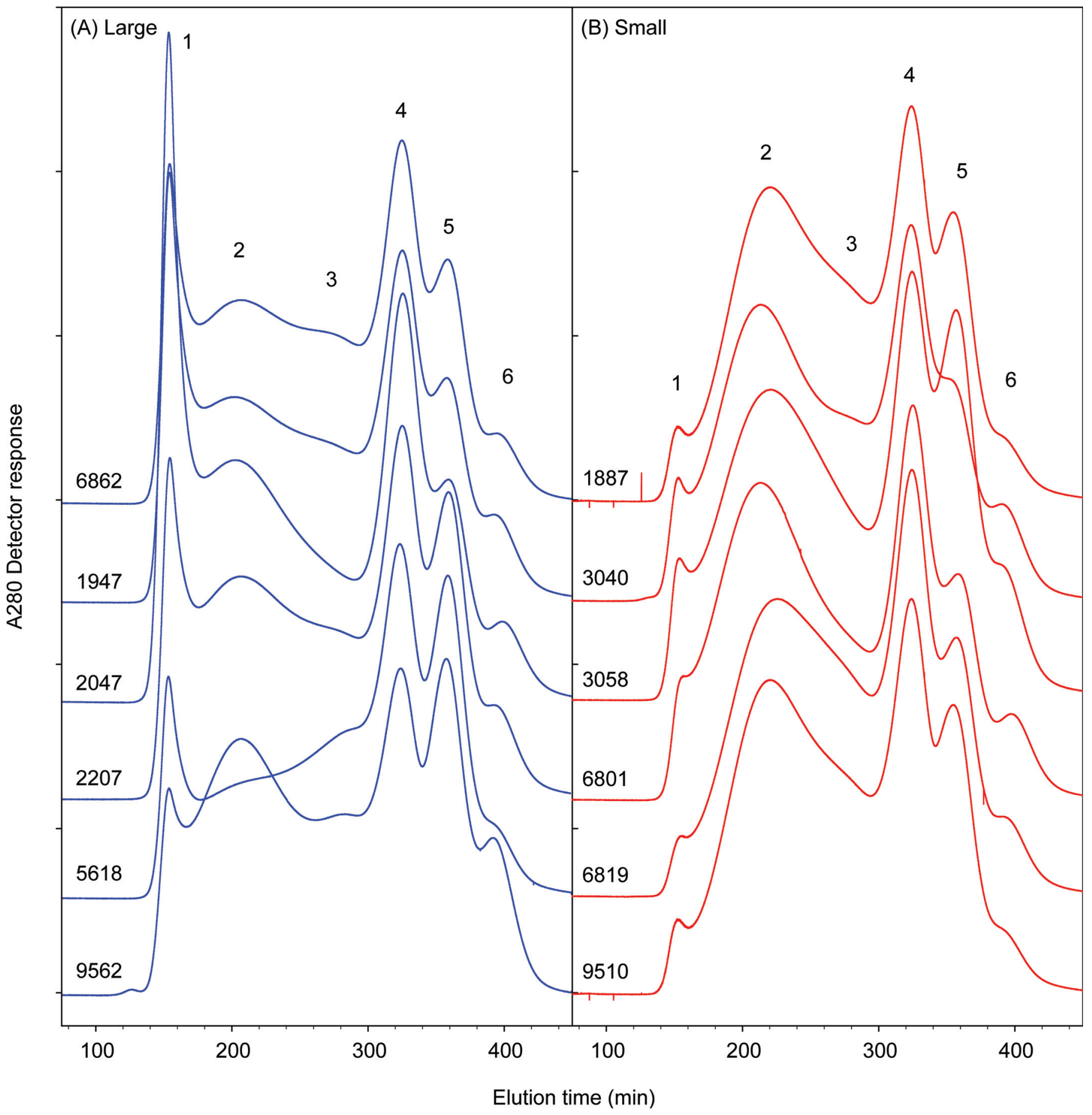

Figure 1. Typical patterns shown for milks with (A) large, and (B) small casein micelles when analyzed by size exclusion-HPLC. Six cows (indicated) representing typical patterns were selected from the 15 cows in each group as examples. Peak $1=$ particles with diameters $>200 \mathrm{~nm}$, large casein micelles; peak $2=$ particles with diameters in the range 160 to $80 \mathrm{~nm}$, casein micelles; peak $3=$ particle diameters 80 to $37 \mathrm{~nm}$, comprising large, medium, and small aggregated proteins, respectively; peak $4=$ whey proteins; peak $5=$ small peptides; and peak $6=$ small aromatic molecules. Color version available online. 

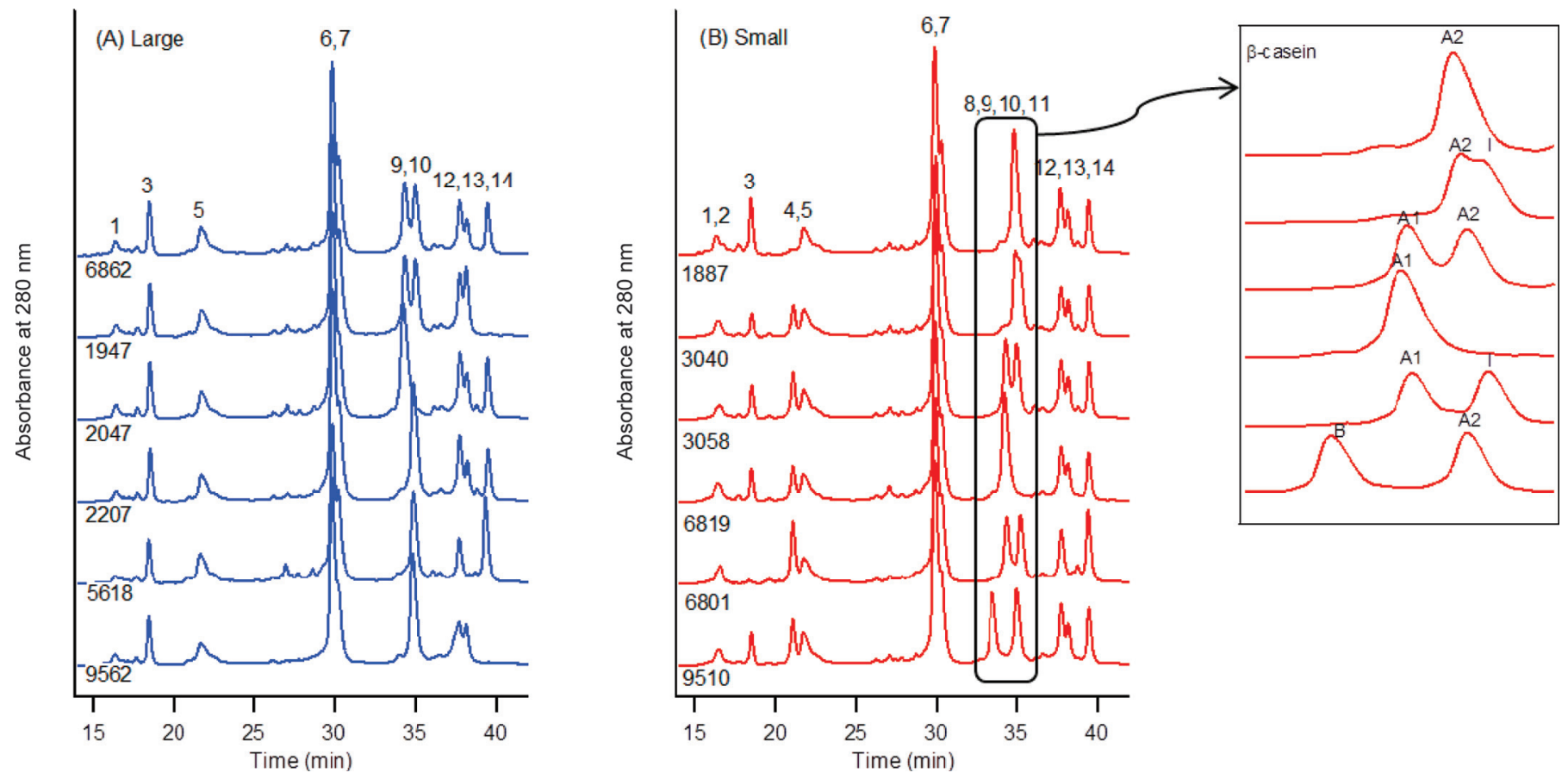

Figure 2. Typical reversed phase-HPLC chromatograms shown for milks with average (A) large, and (B) small casein micelles. Six cows (indicated) representing typical casein and whey protein polymorphism were selected from the 15 cows in each group as examples. Peak numbers for identification of casein and whey proteins correspond to the peak numbers in Table 2. Color version available online.

\section{Variation in Casein Phenotypes and Relative Amounts}

The individual casein proteins in each milk sample were analyzed by RP-HPLC. The selected RP-HPLC profiles from the large casein micelle and small micelle groups are shown in Figure 2. The molecular weights of the caseins corresponding to the different RP-HPLC peaks, which were identified by their masses using LCMS, are summarized in Table 2.

Pronounced phenotype differences between the large and small micelle groups were observed for the $\kappa$-CN variants (Table 1). Within milk samples with the large micelles, all cows were homozygous AA for $\kappa-\mathrm{CN}$, whereas milks with small micelles predominantly contained both $\kappa-\mathrm{CN} \mathrm{A}$ and $\mathrm{B}$ phenotypes (11 out of 15) although 2 cows were homozygous for $\kappa$-CN AA and 2 were homozygous for $\kappa$-CN BB (Table 1). We also found significant differences in the levels of $\kappa-\mathrm{CN}$ between the 2 groups, with the small micelle group having a significantly higher proportion of $\kappa$-CN relative to total CN at an average of $11.0 \%$, compared with $7.6 \%$ in the large micelle group (Table 3 and Figure 3A). We found no statistical differences in the relative amounts of $\alpha_{\mathrm{S}^{-}}$and $\beta-\mathrm{CN}$ to total $\mathrm{CN}$ between the large and small micelle groups (Table 3 and Figure 3); however, the difference in the relative proportion of $\alpha_{\mathrm{S1}^{-}} \mathrm{CN}$ was significant between the large and small casein groups.
Table 2. Molecular mass of casein proteins; peak numbers correspond to the peak positions in Figure 2

\begin{tabular}{|c|c|c|}
\hline $\begin{array}{l}\text { Peak } \\
\text { no. }\end{array}$ & $\begin{array}{c}\text { Molecular } \\
\text { weight (Da) }\end{array}$ & Casein species and variant $^{2}$ \\
\hline 1 & 20,932 & $\kappa-\mathrm{CN} \mathrm{A}(1 \mathrm{P})+2$ GalNAc-Gal-(NeuAC) \\
\hline \multirow[t]{2}{*}{2} & 20,900 & $\kappa-\mathrm{CN} B(1 \mathrm{P})+2$ GalNAc-Gal-(NeuAC) \\
\hline & 19,983 & $\kappa-\mathrm{CN} A(1 \mathrm{P})+1$ GalNAc-Gal-(NeuAC) \\
\hline 3 & 19,034 & $\kappa-\mathrm{CN}$ A $(1 \mathrm{P})$ \\
\hline 4 & 19,002 & $\kappa-\mathrm{CN} B(1 \mathrm{P})$ \\
\hline \multirow[t]{2}{*}{5} & 25,225 & $\alpha_{S_{2}-} \mathrm{CN} A(11 \mathrm{P})$ \\
\hline & 25,304 & $\alpha_{\mathrm{S}_{2}}-\mathrm{CN} \mathrm{A}(11 \mathrm{P})+1 \mathrm{P}$ \\
\hline \multirow[t]{2}{*}{6} & 23,611 & $\alpha_{S_{1}-}-\mathrm{CN} \mathrm{B}(8 \mathrm{P})$ \\
\hline & 23,690 & $\alpha_{\mathrm{S}^{-}}-\mathrm{CN} \mathrm{B}(8 \mathrm{P})+1 \mathrm{P}$ \\
\hline \multirow[t]{2}{*}{7} & 23,691 & $\alpha_{S_{1}-} \mathrm{CN} \mathrm{B}(8 \mathrm{P})+1 \mathrm{P}$ \\
\hline & 23,610 & $\alpha_{\mathrm{S} 1}-\mathrm{CN} B(8 \mathrm{P})$ \\
\hline 8 & 24.088 & $\beta-\mathrm{CN} B(5 \mathrm{P})$ \\
\hline 9 & 24,109 & $\beta-\mathrm{CN} \mathrm{A}^{1}(5 \mathrm{P})$ \\
\hline 10 & 23,983 & $\beta-\mathrm{CN} \mathrm{A}^{2}(5 \mathrm{P})$ \\
\hline 11 & 23,965 & $\beta-\mathrm{CN}$ I $(5 \mathrm{P})$ \\
\hline 12 & 14,186 & $\alpha-\mathrm{LA}$ \\
\hline 13 & 18,278 & $\beta-L G$ B \\
\hline 14 & 18,363 & $\beta-\mathrm{LG} \mathrm{A}$ \\
\hline
\end{tabular}

${ }^{1}$ Fractions corresponding to each peak were collected from the reversed phase-HPLC analysis and freeze-dried, resolubilized in $0.1 \%$ formic acid, and analyzed by liquid chromatography-mass spectrometry.

${ }^{2}$ Casein phenotypes and the number of phosphoryl (P) and glycosyl residues were identified according to their theoretical molecular weights (Saito and Itoh, 1992; Farrell et al., 2004); GalNAc-Gal-(NeuAC) = $N$-acetylglucosamine-galactose- $N$-acetylneuraminic acid. 
Table 3. The relative proportions of individual caseins to total casein based on the peak areas measured in reversed phase-HPLC

\begin{tabular}{|c|c|c|c|}
\hline \multirow[b]{2}{*}{ Casein (\% casein/total casein) } & \multicolumn{2}{|c|}{ Casein micelle group } & \multirow[b]{2}{*}{$P$-value } \\
\hline & Large & Small & \\
\hline$\alpha_{\mathrm{S} 1}-\mathrm{CN}(\%)^{*}$ & $39.1 \pm 2.1$ & $34.0 \pm 2.5$ & 0.017 \\
\hline$\alpha_{\mathrm{S} 2}-\mathrm{CN}(\%)$ & $7.5 \pm 1.0$ & $7.0 \pm 1.0$ & 0.16 \\
\hline$\beta-\mathrm{CN}(\%)$ & $45.7 \pm 2.7$ & $45.0 \pm 2.7$ & 0.45 \\
\hline$\kappa-\mathrm{CN}(\%) *$ & $7.6 \pm 0.6$ & $11.0 \pm 0.7$ & $<0.001$ \\
\hline Glycosylated $(\%)^{*}$ & $2.18 \pm 0.34$ & $4.07 \pm 0.58$ & $<0.001$ \\
\hline Nonglycosylated (\%) * & $5.42 \pm 0.40$ & $6.94 \pm 0.65$ & $<0.001$ \\
\hline Glycosylated:nonglycosylated* & $0.40 \pm 0.06$ & $0.60 \pm 0.11$ & $<0.001$ \\
\hline
\end{tabular}

*Statistically significant difference $(P<0.05)$ between the large and small micelle groups.
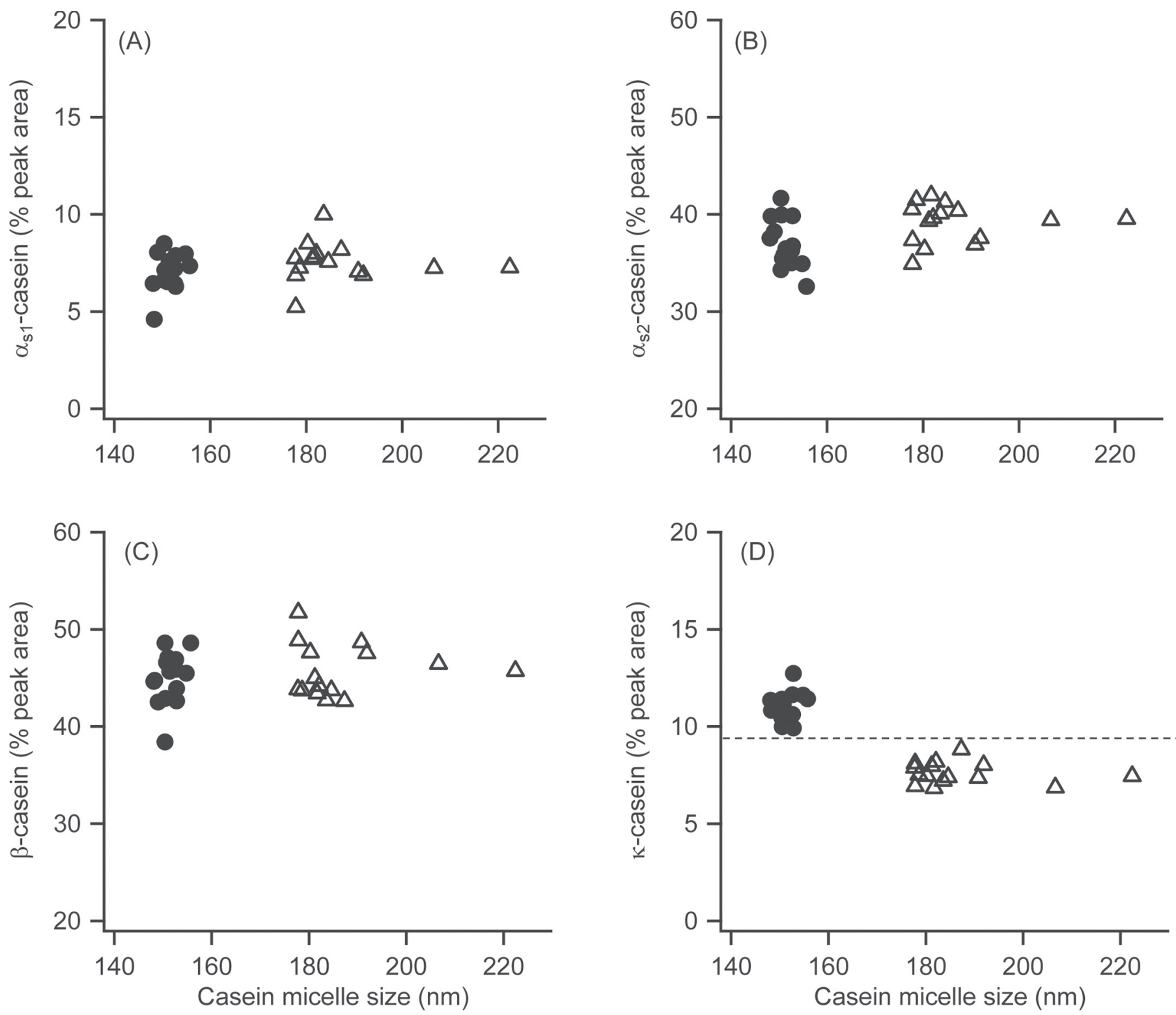

Figure 3. The relative proportions (\%) of (A) $\alpha_{\mathrm{S}^{-}} \mathrm{CN}$, (B) $\alpha_{\mathrm{S} 2}-\mathrm{CN},(\mathrm{C}) \beta-\mathrm{CN}$, and (D) $\kappa$-CN to total CN based on reversed phase-HPLC peak areas, in individual milk samples with small $(\bullet)$ and large $(\Delta)$ casein micelles. The dotted line indicates significant difference between the 2 groups $(P<0.001)$. 
These results corroborate the findings of others that average casein micelle size in $\kappa$-CN AA milk tends to be larger than that in $\kappa-\mathrm{CN} \mathrm{AB}$ or BB milks (Lodes et al., 1996; Walsh et al., 1998; Ng-Kwai-Hang et al., 2002; Glantz et al., 2010; Bijl et al., 2014). The negative correlation between micelle size and $\kappa$-CN content has been widely reported in bulk milk where micelles were fractionated to different sizes (Davies and Law, 1983; Dalgleish et al., 1989). However, the recent studies by de Kruif and Huppertz (2012) and Bijl et al. (2014) on milks from individual cows found no statistically significant differences between casein micelle size and the relative amount of $\kappa$ - $\mathrm{CN}$ to total proteins.

\section{Small Casein Micelle Milks Have a High Proportion of Glycosylated $k$-Casein}

Further quantitative analyses based on HPLC peak areas were carried out to investigate whether the difference in the total amount of $\kappa-\mathrm{CN}$ is associated with the extent of $\kappa$-CN glycosylation for differently sized casein micelles. Thus, the proportions of glycosylated and nonglycosylated $\kappa-\mathrm{CN}$, relative to total $\mathrm{CN}$, respectively, and the ratio of glycosylated:nonglycosylated $\kappa$-CN in the individual milk samples among the small and large casein micelle groups were calculated and are shown in Figure 4.

Milks with small casein micelles had higher proportions of both glycosylated and nonglycosylated $\kappa-\mathrm{CN}$ relative to total $\mathrm{CN}$, compared with the large casein micelle milks (Figure $4 \mathrm{~A}$ and $4 \mathrm{~B}$ ). The difference in the relative amount of glycosylated $\kappa-\mathrm{CN}$ to total $\mathrm{CN}$ between the small and large casein micelle groups was significant $(P<0.001)$. The average amount of glycosylated $\kappa$-CN relative to total casein was $4.07 \%$ for the small micelle group, which was nearly twice the amount for the large micelle group (2.18\%; Table 3$)$. There were also differences in the relative amount of nonglycosylated $\kappa-\mathrm{CN}$ to total $\mathrm{CN}$ between the small and large micelle groups - an average of $6.94 \%$ in the small micelle group compared with $5.42 \%$ in the large micelle group (Table 3). However, the differences in the relative amounts of nonglycosylated $\kappa-\mathrm{CN}$ to total $\mathrm{CN}$ between the small micelle group (5.42\%) and the large micelle group (6.94\%) were smaller than the differences in their relative amounts of glycosylated $\kappa-\mathrm{CN}$. This is better illustrated by the ratio of glycosylated:nonglycosylated $\kappa-\mathrm{CN}$, which was higher for the small casein micelles (0.6) than that for the large casein micelles (0.4; Figure $4 \mathrm{C}$, Table 3 ). The results suggest that the higher amount of total $\kappa-\mathrm{CN}$ in small compared with large micelles was due primarily to the higher amount of glycosylated $\kappa$-CN content.
Bijl et al. (2014) found a significant difference $(P<$ 0.001 ) in the relative amounts of glycosylated $\kappa$-CN between the $\mathrm{AA}$ and $\mathrm{AB}$ genotypes; milk with the $\kappa-\mathrm{CN}$ AA had less glycosylated $\kappa$-CN compared with the $\kappa-\mathrm{CN} \mathrm{AB}$ milks, which agrees with the findings of the current study. However, we also observed that the relative amount of nonglycosylated $\kappa-\mathrm{CN}$ to total $\kappa-\mathrm{CN}$ was closely associated with the type of $\kappa-\mathrm{CN}$ variant present in the milk; that is, those with $\kappa-\mathrm{CN}$ AA (all large micelles plus 2 of the small micelles) had the lower proportion of nonglycosylated $\kappa-\mathrm{CN}$ to total $\kappa-\mathrm{CN}(5.95-6.04 \%)$ compared with milks with $\kappa$-CN $\mathrm{AB}$ and $\mathrm{BB}$ variants (only small casein micelles), where the relative amount of nonglycosylated $\kappa-\mathrm{CN}$ to total $\kappa$-CN was 6.10 to $8.05 \%$. Differences in the levels of glycosylated $\kappa-\mathrm{CN}$ between the $\mathrm{AB}$ and $\mathrm{AA}$ milks have been reported by others (Robitaille et al., 1991). The trends seen in the current study are consistent with that of Lodes et al. (1996), who showed that the $\kappa-C N$ genotype BB had a $44 \%$ higher proportion of nonglycosylated $\kappa-\mathrm{CN}$ in total protein than the AA genotype and that an increase in the content of nonglycosylated $\kappa-\mathrm{CN}$ was associated with a decrease in micelle size.

According to the molecular weights as identified by LC-MS (Table 2), the major forms of glycans found in glycosylated $\kappa-\mathrm{CN}$ in this study were the tetrasaccharide composed of $N$-acetylgalactosamine, galactose, and 2 neuraminic acid groups, as previously reported (Saito and Itoh, 1992).

\section{Small Casein Micelle Group Has High Heterogeneity in $\beta$-Casein Variants}

$\beta$-Casein phenotype variants were also identified according to their molecular weights (Table 2). The B variant of $\beta-\mathrm{CN}$ was only found in milk samples containing small micelles (Table 1 ). In addition, the I variant of $\beta$-CN was only identified in several milk samples in the small micelle group. The I variant could be seen in RP-HPLC chromatograms as a small shift from the $\beta-\mathrm{CN} \mathrm{A}{ }^{2}$ peak (Figure 2B). The molecular weight of this peak was subsequently confirmed by MS, matching that of $\beta-\mathrm{CN}$ variant I with a single amino acid substitution of $\mathrm{Met}^{93}$ to $\mathrm{Leu}^{93}$ and a reduction in molecular weight of 18 Da from $\beta-\mathrm{CN} \mathrm{A}^{2}$ (Farrell et al., 2004).

The 3 most prevalent $\beta-\mathrm{CN}$ variants, $\mathrm{A}^{1} \mathrm{~A}^{1}, \mathrm{~A}^{1} \mathrm{~A}^{2}$, and $\mathrm{A}^{2} \mathrm{~A}^{2}$, were found in all milks with large micelles and just over half of the milk samples with small micelles, suggesting that micelle size does not appear to be associated with the $\beta$-CN A variant. However, most of the milks with $\beta-\mathrm{CN} \mathrm{A}{ }^{2} \mathrm{~A}^{2}$ (6 of 7) fell in the large micelle group, whereas $\beta-\mathrm{CN} \mathrm{A}^{1} \mathrm{~A}^{1}$ and $\mathrm{A}^{1} \mathrm{~A}^{2}$ variants were equally frequent among the cows with large and 

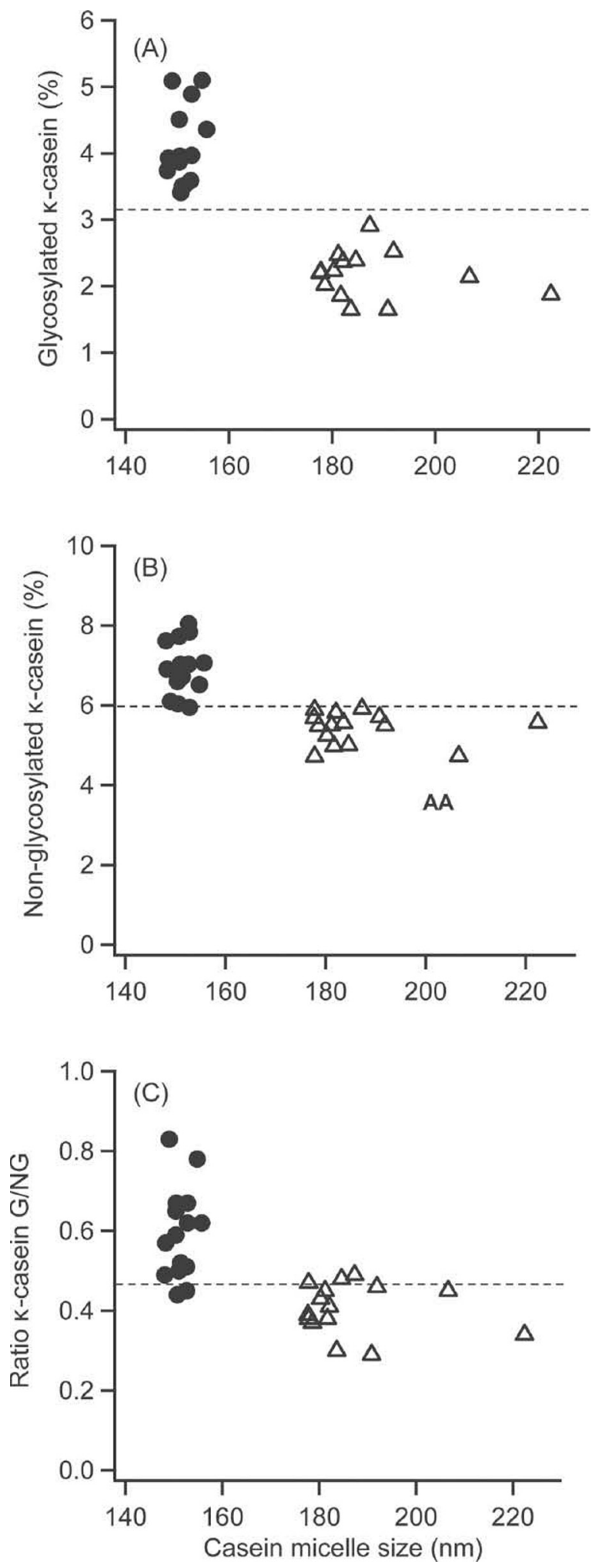

Figure 4. The relative proportion (\%) of (A) glycosylated $\kappa-\mathrm{CN}$, and (B) nonglycosylated $\kappa-\mathrm{CN}$ to total $\mathrm{CN}$ based on reversed phaseHPLC peak areas, and (C) ratio of glycosylated $(\mathrm{G})$ to nonglycosylated $(\mathrm{NG}) \mathrm{k}-\mathrm{CN}$ in individual milk samples with small $(\bullet)$ and large $(\Delta)$ casein micelles. The dotted line indicates significant difference between the 2 groups $(P<0.001)$. small micelles. On the other hand, there was considerable heterogeneity in $\beta-\mathrm{CN}$ phenotypes among the milks with small micelles (Table 1 ). Five of the 15 cows in the small micelle group had a combination of I with either $\mathrm{A}^{1}$ or $\mathrm{A}^{2}$, and 2 had $\mathrm{B}$ in combination with either $\mathrm{A}^{2}$ or I. None of these variant combinations were found in any of the cows producing large casein micelles.

Lodes et al. (1996) found that milks with $\beta$-CN BB had smaller micelle sizes compared with milks from cows with the genotype $\mathrm{A}^{1} \mathrm{~A}^{1}$, but not in the case of $\mathrm{A}^{2} \mathrm{~A}^{2}$. Those authors found that micelles from cows with the genotype of $\mathrm{A}^{1} \mathrm{~A}^{1} \beta-\mathrm{CN}$ (203 nm) were, on average, significantly larger than those with $\mathrm{A}^{1} \mathrm{~A}^{2}$ (191 $\mathrm{nm})$ and $\mathrm{A}^{2} \mathrm{~A}^{2}(185 \mathrm{~nm})$ micelles. In addition, they found that micelles from cows with genotype $\mathrm{A}^{1} \mathrm{~B}(205$ $\mathrm{nm}$ ) were also significantly larger than $\mathrm{A}^{1} \mathrm{~A}^{2}$ and $\mathrm{A}^{2} \mathrm{~A}^{2}$ and $\mathrm{A}^{2} \mathrm{~B}$ micelles. These results were somewhat opposite to the findings of current study, where we found all 3 heterozygous from $\mathrm{A}$ genotype (e.g., $\mathrm{A}^{1} \mathrm{~A}^{1}, \mathrm{~A}^{1} \mathrm{~A}^{2}$, and $\left.\mathrm{A}^{2} \mathrm{~A}^{2}\right)$ in both the small and large micelle groups. This could be because the micelle size range covered in this study was much wider (small group: 148 to $155 \mathrm{~nm}$; large group: 178 to $222 \mathrm{~nm}$ ) compared with the study of Lodes et al. (1996).

\section{$\beta$-LG Phenotypes}

Three $\beta$-LG phenotypes were found, from the genetically homozygous $\mathrm{AA}$ and $\mathrm{BB}$ and heterozygous $\mathrm{AB}$ variants. All 3 phenotypes were present in both large and small micelle milk groups, with $\mathrm{AB}$ being the most common variant across the 30 individual milk samples examined in this study. $\beta$-Lactoglobulin phenotypes do not appear to have any particular association with casein genetic variants or with the size of the casein micelle (Table 1).

Previous studies have shown both an association (Lodes et al., 1996; Ng-Kwai-Hang et al., 2002) and no association (this work; Devold et al., 2000) between $\beta$-LG phenotype and micelle size. Differences in study design or cow selection may have contributed to the variation in results.

\section{DISCUSSION}

Milk samples from 30 Holstein-Friesian individual cows were selected on the basis of having either "large" or "small" casein micelle size. Within the large group, casein micelle sizes ranged between 177 and $222 \mathrm{~nm}$, whereas size in the small group ranged between 148 and $155 \mathrm{~nm}$. The large micelle milks were found to contain only $\kappa-\mathrm{CN}$ phenotype $\mathrm{AA}$, whereas $\kappa-\mathrm{CN}$ phenotypes $\mathrm{AA}, \mathrm{AB}$, and $\mathrm{BB}$ were found among the $15 \mathrm{milk}$ samples with small casein micelle sizes. Similarly, the 
large micelle milks contained only $3 \beta$-CN phenotypes, $\mathrm{A}^{1} \mathrm{~A}^{1}, \mathrm{~A}^{1} \mathrm{~A}^{2}$, and $\mathrm{A}^{2} \mathrm{~A}^{2}$, whereas a considerable mix of phenotypes, including genetic variants of $\mathrm{B}$ and $\mathrm{I}$, were identified in the small micelle milk samples. Thus, the phenotype co-variants of $\kappa$ - and $\beta$-CN were much more diverse among the 15 small micelle milk samples compared with those in the milk with large micelles.

In addition to the diverse phenotype variants, the relative amount of $\kappa-\mathrm{CN}$ to total $\mathrm{CN}$ was found to be significantly higher in the small micelle group compared with the large micelle group. The greater amount of $\kappa-\mathrm{CN}$ in the small group was mainly attributed to a higher amount of glycosylated $\kappa$-CN. It is known that $\kappa-\mathrm{CN} \mathrm{B}$ variant is more highly glycosylated than the A variant, with an apparently greater number of oligosaccharide chains per peptide unit and a higher level of sialylation (Coolbear et al., 1996), even though the B variant ( $\mathrm{Ile}^{157}$ ) has one fewer Thr than the A variant (Thr ${ }^{157}$; Farrell et al., 2004; Holland, 2009). The heterozygous mixed variant of $\mathrm{AB}$ is a composite of the individual variants. Our results from the milks containing small casein micelles where the majority were $\kappa$-CN $\mathrm{AB}$ compared with milks with large micelles, with only AA phenotypes, also appeared to suggest that $\kappa-\mathrm{CN} B$ was more glycosylated than the A variant. This would support a hypothesis that glycosylation of $\kappa-\mathrm{CN}$ has the predominant influence on terminating casein micelle growth, and is thus a key limiting factor of micelle size. This is also supported by the fact that when a high proportion of glycosylated $\kappa$-CN was produced with the A variant, smaller casein micelles were produced. This implies that the amount of glycosylated $\kappa-\mathrm{CN}$ might be the major factor influencing casein micelle size, and may override the genotypic effects. Analysis of a much larger group of milk samples from individual cows of known genotypes would be needed to confirm this hypothesis.

$\beta$-Casein variants are increasingly being recognized as playing a role in rennet curd formation of milk (Bittante et al., 2012). Several recent studies have shown that milks with $\beta-\mathrm{CN} \mathrm{A}^{2} \mathrm{~A}^{2}$ in combination with $\kappa-\mathrm{CN}$ AA variants tend to have poor renneting coagulation properties or do not coagulate at all (Frederiksen et al., 2011; Jensen et al., 2012a, b; Vallas et al., 2012; Poulsen et al., 2013). Others have also shown an association between the $\mathrm{A}^{2} \beta-\mathrm{CN}$ genotype and the $\mathrm{A} \kappa-\mathrm{CN}$ genotype and poorly coagulating or noncoagulating milks in Jersey and Holstein-Friesian cows (Jensen et al., 2012a,b). The latter authors showed that milk with the $\mathrm{A}^{2} \mathrm{~A}^{2} \beta$-CN genotype and the $\mathrm{AA} \kappa-\mathrm{CN}$ genotype were the predominant genotypes in poorly coagulating or noncoagulating milk and that these milks had lower total protein, lower total $\mathrm{CN}$, and lower $\kappa$-CN contents, as well as lower minerals ( $\mathrm{Ca}, \mathrm{P}$, and $\mathrm{Mg}$ ). Poulsen et al. (2013) confirmed the same link with the $\mathrm{A}^{2} \mathrm{~A}^{2} \beta$-CN genotype and poorly coagulating milk in 3 Scandinavian breeds, Danish Holstein, Danish Jersey, and Swedish Red. Although the links between $\beta$-CN A variants (e.g., $\mathrm{A}^{1}$ vs. $\mathrm{A}^{2}$ ) and the gelation properties of milks appear to be evident, little has been reported on the possible association of $\beta$-CN variants with micelle size. In the current study, $\mathrm{A}^{1}$ and $\mathrm{A}^{2}$ homozygous and $\mathrm{A}^{1} \mathrm{~A}^{2}$ heterozygous of $\beta-\mathrm{CN}$ were found in both large and small casein micelle groups, although $\beta-\mathrm{CN} \mathrm{A}^{2} \mathrm{~A}^{2}$ were predominantly found in the large micelle group $(6$ out of 7 milk samples), whereas $\beta-\mathrm{CN} \mathrm{A} \mathrm{A}^{2}$ and $\beta$-CN $\mathrm{A}^{1} \mathrm{~A}^{1}$ were more evenly distributed between the large and small micelle groups. However, we found no statistical difference in the total protein content of milk samples with different $\beta$-CN phenotypes in this study (Table 2). It appears that the poor coagulation properties of milk containing $\kappa-\mathrm{CN}$ AA and $\beta-\mathrm{CN} \mathrm{A}{ }^{2} \mathrm{~A}^{2}$ could be associated with casein micelle size.

Other $\beta$-CN phenotypes such as B and I contain similar phosphorylation sites of $\beta-\mathrm{CN}$, which are critical for the formation of internal micellar structure via calcium phosphate nanoparticles; however, changes in a single amino acid might alter local conformation of the protein, thereby affecting the packing of the internal structure and asymmetric growth of casein micelles. This has been shown for milks containing the A or B genetic variants of $\alpha_{S_{1}}-\mathrm{CN}$, in which colloidal micelles were packed much more densely for the A variant (e.g., at a ratio of $6: 1)$ compared with the $\mathrm{B}$ variant $(3: 1$; Kumosinski et al., 1991). How such genetic diversity of the $\beta$-CN might influence the internal packing of the casein micelle structure and whether it plays any role in casein micelle size and the functional properties of milk remain to be investigated.

Our recent work on purified $\mathrm{A}^{1}$ and $\mathrm{A}^{2}$ structural selfassembly behavior has also indicated that the genetic diversity of $\beta-\mathrm{CN}$ might influence the internal structure of casein micelle assembly and possibly monomer-micelle equilibrium (Raynes et al., 2015). Nonhomogeneity of $\beta$-CN could limit the symmetric assembly and growth of casein micelles. Another possibility is the equilibrium of micellar caseins and monomer caseins in serum. Further examination of the fine assembly structure of casein micelles from individual milk of known genetic background (e.g., $\kappa-\mathrm{CN}$ AA or BB in combination with different $\beta$-CN variants) may shed further light on the role of single amino acid substitution or posttranslational modification on the differences in the assembly behavior of caseins.

It appears that increasing the diversity of $\beta-\mathrm{CN}$ and $\kappa-\mathrm{CN}$ as well as the amount of glycosylated $\kappa-\mathrm{CN}$ 
would favor the production of smaller casein micelles. Further examination of a large number of milk samples from individual cows of known genetics and linking this information to composition, including mineral contents and the physical properties (e.g., gelation), may confirm the findings of this work and generate new insights into the importance of casein polymorphisms in relation to casein micelle size and milk functionality. Such knowledge could allow for gene selection to improve the productive and nutritional value of bovine milk and set new raw material selection criteria for improving processing efficiency.

\section{ACKNOWLEDGMENTS}

The authors acknowledge the assistance from Martin Auldist, Jae Greenwood, and staff from the Ellinbank research farm of Victorian Department of Environment and Primary Industries (Victoria, Australia) for the collection of milk samples and provision of information concerning cow management and feeding, and Amirtha Puvanenthiran (CSIRO Food \& Nutrition Flagship, Werribee, Australia) for providing the casein micelle size and total protein content analyses.

\section{REFERENCES}

Bijl, E., R. de Vries, H. van Valenberg, T. Huppertz, and T. van Hooijdonk. 2014. Factors influencing casein micelle size in milk of individual cows: Genetic variants and glycosylation of $\kappa$-casein. Int. Dairy J. 34:135-141.

Bingham, E. W., and H. M. Farrell. 1974. Casein kinase from Golgi apparatus of lactating mammary-gland. J. Biol. Chem. 249:36473651.

Bittante, G., M. Penasa, and A. Cecchinato. 2012. Invited review: Genetics and modeling of milk coagulation properties. J. Dairy Sci. 95:6843-6870.

Bobe, G., D. C. Beitz, A. E. Freeman, and G. L. Lindberg. 1998. Separation and quantification of bovine milk proteins by reversedphase high-performance liquid chromatography. J. Agric. Food Chem. 46:458-463.

Bordin, G., F. C. Raposo, B. de la Calle, and A. R. Rodriguez. 2001. Identification and quantification of major bovine milk proteins by liquid chromatography. J. Chromatogr. A 928:63-76.

Coolbear, K. P., D. F. Elgar, and J. S. Ayers. 1996. Profiling of genetic variants of bovine kappa-casein macropeptide by electrophoretic and chromatographic techniques. Int. Dairy J. 6:1055-1068.

Dalgleish, D. G. 1986. Analysis by fast protein liquid-chromatography of variants of kappa-casein and their relevance to micellar structure and renneting. J. Dairy Res. 53:43-51.

Dalgleish, D. G. 2011. On the structural models of bovine casein micelles-Review and possible improvements. Soft Matter 7:22652272 .

Dalgleish, D. G., D. S. Horne, and A. J. R. Law. 1989. Size-related differences in bovine casein micelles. Biochim. Biophys. Acta 991:383-387.

Davies, D. T., and A. J. R. Law. 1983. Variation in the protein composition of bovine casein micelles and serum casein in relation to micellar size. J. Dairy Res. 50:67-75.

de Kruif, C. G., and T. Huppertz. 2012. Casein micelles: Size distribution in milks from individual cows. J. Agric. Food Chem. 60:4649-4655.
Devold, T. G., M. J. Brovold, T. Langsrud, and G. E. Vegarud. 2000. Size of native and heated casein micelles, content of protein and minerals in milk from Norwegian Red cattle - Effect of milk protein polymorphism and different feeding regimes. Int. Dairy J. 10:313-323.

Dziuba, J., and P. Minkiewicz. 1996. Influence of glycosylation on micelle-stabilizing ability and biological properties of C-terminal fragments of cow's kappa-casein. Int. Dairy J. 6:1017-1044.

Farrell, H. M., R. Jimenez-Flores, G. T. Bleck, E. M. Brown, J. E. Butler, L. K. Creamer, C. L. Hicks, C. M. Hollar, K. F. Ng-KwaiHang, and H. E. Swaisgood. 2004. Nomenclature of the proteins of cows' milk - Sixth revision. J. Dairy Sci. 87:1641-1674.

Farrell, H. M., E. L. Malin, E. M. Brown, and P. X. Qi. 2006. Casein micelle structure: What can be learned from milk synthesis and structural biology? Curr. Opin. Colloid Interface Sci. 11:135-147.

Frederiksen, P. D., K. K. Andersen, M. Hammershoj, H. D. Poulsen, J. Sorensen, M. Bakman, K. B. Qvist, and L. B. Larsen. 2011. Composition and effect of blending of noncoagulating, poorly coagulating, and well-coagulating bovine milk from individual Danish Holstein cows. J. Dairy Sci. 94:4787-4799.

Glantz, M., T. G. Devold, G. E. Vegarud, H. L. Mansson, H. Stalhammar, and M. Paulsson. 2010. Importance of casein micelle size and milk composition for milk gelation. J. Dairy Sci. 93:1444-1451.

Holland, J. W. 2009. Post-translational modifications of caseins. Pages 107-132 in Milk Proteins: From Expression to Food. Elsevier Academic Press Inc., San Diego, CA.

Holt, C. 1992. Structure and stability of bovine casein micelles. Adv. Protein Chem. 43:63-151.

Holt, C., and J. A. Carver. 2012. Darwinian transformation of a 'scarcely nutritious fluid' into milk. J. Evol. Biol. 25:1253-1263.

Horne, D. S. 2006. Casein micelle structure: Models and muddles. Curr. Opin. Colloid Interface Sci. 11:148-153.

Horne, D. S. 2009. Casein micelle structure and stability. Pages 133 162 in Milk Proteins. A. Thompson, M. Boland, and H. Singh, ed. Academic Press, San Diego, CA.

Jensen, H. B., J. W. Holland, N. A. Poulsen, and L. B. Larsen. 2012a. Milk protein genetic variants and isoforms identified in bovine milk representing extremes in coagulation properties. J. Dairy Sci. 95:2891-2903.

Jensen, H. B., N. A. Poulsen, K. K. Andersen, M. Hammershøj, H. D. Poulsen, and L. B. Larsen. 2012b. Distinct composition of bovine milk from Jersey and Holstein-Friesian cows with good, poor, or noncoagulation properties as reflected in protein genetic variants and isoforms. J. Dairy Sci. 95:6905-6917.

Kumosinski, T. F., H. Pessen, E. M. Brown, L. T. Kakalis, and H. M. Farrell. 1991. Quaternary structural-changes of bovine casein by small-angle x-ray-scattering-Effect of genetic-variation. ACS Symp. Ser. 454:182-194.

Lodes, A., I. Krause, J. Buchberger, J. Aumann, and H. Klostermeyer. 1996. The influence of genetic variants of milk proteins on the compositional and technological properties of milk. 1. Casein micelle size and the content of non-glycosylated kappa-casein. Milchwissenschaft 51:368-373.

McGann, T. C. A., W. J. Donnelly, R. D. Kearney, and W. Buchheim. 1980. Composition and size distribution of bovine casein micelles. Biochim. Biophys. Acta 630:261-270.

Ng-Kwai-Hang, K. F., D. E. Otter, E. Lowe, M. J. Boland, and M. J. Auldist. 2002. Influence of genetic variants of beta-lactoglobulin on milk composition and size of casein micelles. Milchwissenschaft 57:303-306.

O'Connell, J. E., and P. F. Fox. 2000. The two-stage coagulation of milk proteins in the minimum of the heat coagulation time-pH profile of milk: Effect of casein micelle size. J. Dairy Sci. 83:378-386.

Poulsen, N. A., H. P. Bertelsen, H. B. Jensen, F. Gustavsson, M. Glantz, H. Lindmark Månsson, A. Andrén, M. Paulsson, C. Bendixen, A. J. Buitenhuis, and L. B. Larsen. 2013. The occurrence of noncoagulating milk and the association of bovine milk coagulation properties with genetic variants of the caseins in 3 Scandinavian dairy breeds. J. Dairy Sci. 96:4830-4842.

Raynes, J. K., L. Day, M. A. Augustin, and J. C. Carver. 2015. Structural differences between bovine A1 and A2 $\beta$-casein alter micelle 
self-assembly and influence molecular chaperone activity. J. Dairy Sci. 98:2172-2182. http://dx.doi.org/10.3168/jds.2014-8800.

Robitaille, G., K. F. Ng-Kwai-Hang, and H. G. Monardes. 1991. Association of kappa-casein glycosylation with milk-production and composition in holsteins. J. Dairy Sci. 74:3314-3317.

Saito, T., and T. Itoh. 1992. Variations and distributions of o-glycosidically linked sugar chains in bovine kappa-casein. J. Dairy Sci. $75: 1768-1774$.

Takeuchi, M., E. Tsuda, M. Yoshikawa, R. Sasaki, and H. Chiba. 1984 Post-translational modification of k-casein in the Golgi apparatus of mid-lactating mammary-glands from rat and cow. Agric. Biol. Chem. 48:2789-2797.

Vallas, M., T. Kaart, S. Varv, K. Parna, I. Joudu, H. Viinalass, and E. Parna. 2012. Composite beta-kappa-casein genotypes and their effect on composition and coagulation of milk from Estonian Holstein cows. J. Dairy Sci. 95:6760-6769.

Walsh, C. D., T. P. Guinee, W. D. Reville, D. Harrington, J. J. Murphy, B. T. O'Kennedy, and R. J. FitzGerald. 1998. Influence of kappa-casein genetic variant on rennet gel microstructure, cheddar cheesemaking properties and casein micelle size. Int. Dairy J. 8:707-714

Williams, R. P. W., M. J. Auldist, J. Greenwood, and A. Puvanenthiran. 2014. Role of casein micelle size in processing and properties of skim milk powders. Page 31 in 2nd IDF Symposium on Microstructure of Dairy Products, Melbourne, Australia.

Williams, R. P. W., L. D'Ath, and B. Zisu. 2008. Role of protein aggregation in heat-induced heat stability during milk powder manufacture. Dairy Sci. Technol. 88:121-147. 